\title{
Dietary lysine deficiency greatly affects muscle and liver protein turnover in growing chickens*
}

\author{
BY S. TESSERAUD, R. PERESSON, J. LOPES AND A. M. CHAGNEAU \\ Station de Recherches Avicoles, Institut National de la Recherche Agronomique, Centre de Tours- \\ Nouzilly, 37380 Nouzilly, France
}

(Received 2 May 1995 - Revised 7 September 1995 - Accepted 6 October 1995)

\begin{abstract}
We analysed the respective influences of age and lysine deficiency on skeletal muscle and liver protein turnover. Growing male broilers were fed ad libitum on isoenergetic diets containing $200 \mathrm{~g}$ crude protein $/ \mathrm{kg}$ which varied in their lysine content $(7.7$ or $10.1 \mathrm{~g} / \mathrm{kg})$. Fractional rates of protein synthesis (FSR) were measured in vivo in the liver and the pectoralis major muscle of 2-, 3- and 4-week-old chickens (flooding dose of $\mathrm{L}-\left[4-{ }^{3} \mathrm{H}\right]$ phenylalanine). Fractional rates of proteolysis (FBR) were estimated for the same tissues as the difference between synthesis and growth. Over the 2-week period liver FSR and FBR were unchanged, whereas muscle FSR decreased with age. This developmental decline was related to the lower capacity for protein synthesis (Cs) without any modifications of the translational efficiency. Whatever the age, lysine deficiency resulted in significant decreases in body weight, tissue protein content and tissue protein deposition, apparently because of reduced amounts of proteins synthesized. We recorded a difference in the response of the two tissues to lysine deficiency, the pectoralis major being more sensitive than the liver. When comparing birds of the same age, liver FSR and FBR were not modified by the diet, whereas muscle FSR, Cs and FBR were higher in chicks fed on a lysinedeficient diet than in the controls. Conversely, when chicks of similar weights were compared, the main effect of the dietary deficiency was an increase in muscle FBR. The results suggest that lysine deficiency not only delayed chick development so that protein turnover was affected, but also induced greater changes in metabolism. Thus, the principal mechanism whereby muscle mass decreased appeared to be a change in FBR.
\end{abstract}

Lysine: Protein turnover: Chicken

The poultry industry aims to increase the efficiency of the transformation from feed to animal proteins to provide consumers with a product containing more lean and less fat, and to reduce $\mathrm{N}$ excretion which is a source of pollution. At present, synthetic amino acids are added to low-protein diets to obtain a well-balanced feed. A deficiency in a single essential amino acid can indeed disrupt growth mechanisms: it decreases chick growth, feed intake and $\mathrm{N}$ balance (Akinwande \& Bragg, 1985; Okumura et al. 1985; Kino \& Okumura, $1986 a, b)$. It caused a reduced protein deposition in the whole body and in the pectoralis major muscle of 3-week-old chickens mainly because lower amounts of protein were synthesized each day (Kino \& Okumura, 1987; Tesseraud et al. 1992). To our knowledge, all of the studies concerning the effect of an amino acid deficiency have compared chicks at the same chronological age, when chicks fed on a control or an amino acid-deficient diet did not only have different body weights but had, also, different tissue protein masses and different rates of tissue development. To understand better the reduction of growth performance associated with the deficiency of a particular amino acid, we analysed the effect of dietary lysine on in vivo protein turnover using 2-, 3- and 4-week-old chickens. We

* A preliminary report of part of this work has been published in Proceedings of the 9th European Poultry Conference, Glasgow, August 1994, vol. 1, pp. 274-275. 
therefore determined whether age is associated with variations in protein turnover and response to lysine deficiency. Besides, when discussing protein metabolism in chickens, most authors focus on whole body or on breast (pectoralis major) muscle which is the tissue of greatest interest in growing animals. The liver is of major importance in determining the quantity of amino acids utilized and the proportion of whole-body protein synthesized due to its very high fractional synthesis rate (FSR). It seems vital, therefore, to analyse the mechanisms of regulation of protein turnover in both muscle and non-muscle tissues during growth. Thus we measured tissue-protein synthesis rates in pectoralis major muscle (representative of a completely fast-twitch glycolytic muscle type) and in liver, using the reliable flooding-dose method (Garlick et al. 1980, 1994).

\section{MATERIALS AND METHODS}

Animals and experimental design

One-day-old male broilers (ISA-France) were fed ad libitum on either a diet restricted in lysine but well-balanced in other amino acids ( $\mathrm{L}$ diet, $n$ 75) or a control adequate diet (C diet, $n 75$ ) containing 7.7 or $10.1 \mathrm{~g}$ lysine $/ \mathrm{kg}$ respectively. All the diets were isoenergetic $(13.0 \mathrm{MJ}$ metabolizable energy $/ \mathrm{kg})$, had the same protein content $(200 \mathrm{~g} / \mathrm{kg})$ and were in pellet form. The $\mathrm{L}$ diet was based on maize and soyabean meal (Table 1) and the $\mathrm{C}$ diet was formulated from the $\mathrm{L}$ diet by supplementation with crystalline L-lysine $\mathrm{HCl}(3 \mathrm{~g}$ added lysine $/ \mathrm{kg}$ ). During the 4 weeks of the experimental period the birds had free access to water. Relative humidity was maintained at about $45-50 \%$ and the ambient temperature was gradually decreased from $32^{\circ}$ when the birds were $1-\mathrm{d}$-old to $26^{\circ}$ when they were 3 weeks old. The lighting program, after an initial $48 \mathrm{~h}$ of continuous lighting, was reduced to a $16 \mathrm{~h}$ light $-8 \mathrm{~h}$ dark cycle (lights on at 05.00 hours). At 1 week of age (on day 7 ) all the chickens were weighed; for each treatment, forty-eight of them were selected on a body-weight basis (99.9 (SE 11.1) g in chicks fed on the $\mathrm{L}$ diet; 127.5 (SE 13.8) $\mathrm{g}$ in the control chicks) and placed in individual cages. Weights were then recorded weekly (on days 14, 21 and 28). At 2,3 and 4 weeks of age (on days 13-14, 20-22 and 26-28 respectively) we measured growth performances, tissue characteristics and rates of tissue-protein turnover in five to seven chicks from each diet group. The chicks used displayed body weights and growth rates similar to the group mean. Note that fractional protein growth rates (FGR) were evaluated in the same five to seven chicks per age and treatment from the increases in tissue-protein content. For each diet group, regressions were thus established, in which we included additional chicks killed on days $11,18,25$ and 29 (for details, see p. 856).

\section{Protein synthesis measurements}

On the day of the study, feed was removed at 10.30 hours and experiments were carried out between 13.30 and 15.30 hours. Protein FSR were measured in vivo according to the flooding-dose method (McNurlan et al. 1979; Garlick et al. 1980). At 10 min before slaughter, each bird received a single intravenous injection of unlabelled L-phenylalanine $(1500 \mu \mathrm{mol} / \mathrm{kg}$ body weight) combined with $18.5 \mathrm{MBq} / \mathrm{kg}$ body weight of $\mathrm{L}-[4-$ ${ }^{3} \mathrm{H}$ ]phenylalanine (Amersham, $0.96 \mathrm{TBq} / \mathrm{mmol}$ ) to flood the precursor pools. This method, previously validated in chickens by Muramatsu \& Okumura (1985), has been adapted in our laboratory (Tesseraud et al. 1992) and is currently used. In the present study the plasma free $\left[{ }^{3} \mathrm{H}\right]$ phenylalanine specific activity was at least $84 \%$ of the specific activity of the injected phenylalanine in each group. In addition, to determine whether the flooding dose flooded and equilibrated the various precursor pools for protein synthesis, we checked that free phenylalanine specific activities in the liver and in the pectoralis major muscle were close to each other (the liver values were within 91 and $99 \%$ of muscle values) and to the 
Table 1. Composition $(\mathrm{g} / \mathrm{kg})$ of lysine-restricted diet $(L)$

\begin{tabular}{lc}
\hline \hline & \\
Ingredients & 679 \\
Ground maize & 160 \\
Soyabean meal & 100 \\
Maize gluten meal & 20 \\
Rapeseed oil & 5 \\
Vitamin premix* & $3 \cdot 5$ \\
Salt & $1 \cdot 5$ \\
Trace-mineral premix $\dagger$ & 16 \\
Dicalcium phosphate & 14 \\
Calcium carbonate & 1 \\
DL-Methionine & \\
Calculated composition & $13 \cdot 1$ \\
Metabolizable energy (MJ/kg) & $205 \cdot 3$ \\
Crude protein & $9 \cdot 1$ \\
Methionine+cystine & $7 \cdot 7$ \\
Lysine & $9 \cdot 5$ \\
Calcium & 3.4 \\
Available phosphorus & \\
\hline \hline
\end{tabular}

* Vitamin content (/kg premix): retinol $0.6 \mathrm{~g}$, cholecalciferol $7.5 \mathrm{mg}, \alpha$-tocopheryl acetate $3 \mathrm{~g}$, menadione $1 \mathrm{~g}$, nicotinic acid $5 \mathrm{~g}$; thiamin $0.1 \mathrm{~g}$, riboflavin $0.8 \mathrm{~g}$, calcium pantothenate $1.6 \mathrm{~g}$, pyridoxine $0.2 \mathrm{~g}$, cyanocobalamin $1.6 \mathrm{mg}$, pteroylmonoglutamic acid $200 \mathrm{mg}$, biotin $40 \mathrm{mg}$, butylated hydroxytoluene $25 \mathrm{~g}$, choline chloride $100 \mathrm{~g}$, made to $1 \mathrm{~kg}$ with milled oat.

† Mineral content (mg/kg premix): Co 335, Cu 8750, I 1225, Se 225, Zn 84000, Fe 44000, Mn 106000.

specific activity in plasma (muscle values were within 87 and $92 \%$ of plasma values). There was no age or group effect on these values (variance analysis). Just before slaughter, a general anaesthetic (Tiletamine-Zolazepam, Zoletil; Reading, L'Hay-les-Roses, France) was given in the pectoralis major muscle (right side). The birds were decapitated and exsanguinated, then blood was collected in heparinized tubes which were centrifuged. Plasma was collected and frozen. The livers and the left pectoralis major muscles were quickly excised. The livers were rinsed in cold saline $(9 \mathrm{~g} \mathrm{NaCl} / \mathrm{l})$ to remove blood and wiped. Both tissues were weighed and frozen in liquid $\mathbf{N}_{2}$ within 3-4 min after exsanguination. This extra time was not taken into account for the calculation of incorporation time. Plasma, liver and muscle samples were then stored at $-20^{\circ}$ until analysis.

\section{Analytical methods}

To determine the free and protein-bound phenylalanine specific activities, frozen tissues were finely pulverized in liquid $\mathrm{N}_{2}$. To $1 \mathrm{~g}$ of the powder obtained we added $5 \mathrm{ml}$ of cold $0.2 \mathrm{M}-\mathrm{HClO}_{4}$. The acid-soluble fraction containing free amino acids was separated from the protein precipitate by centrifugation $\left(6000 \mathrm{~g}\right.$ for $20 \mathrm{~min}$ ), and $\mathrm{HClO}_{4}$ was neutralized by addition of $0.8-1 \mathrm{ml}$ saturated potassium citrate solution (final $\mathrm{pH} 6 \cdot 4$ ) and centrifugation at $2800 \mathrm{~g}$ for $15 \mathrm{~min}$. The tissue-protein precipitates were washed three more times in cold $0.2 \mathrm{M}-\mathrm{HClO}_{4}$, resuspended in $10 \mathrm{ml} 0.3 \mathrm{M}-\mathrm{NaOH}$ and incubated at $37^{\circ}$ for $1 \mathrm{~h}$. A portion was used to measure tissue-protein content according to the method of Smith et al. (1985), by the colorimetric reaction with bicinchoninic acid (Pierce, Rockford, IL 61 105, USA). We then reprecipitated the protein from the $\mathrm{NaOH}$ solution with $2.5 \mathrm{ml} 2 \mathrm{M}-\mathrm{HClO}_{4}$. The supernatant fraction was used to determine the tissue RNA content (Munro \& Fleck, 1969). We removed last traces of free phenylalanine from the protein pellet by twice washing the pellet with $10 \mathrm{ml} 0.2 \mathrm{M}-\mathrm{HClO}_{4}$ and finally the protein was hydrolysed in $20 \mathrm{ml}$ 
$6 \mathrm{M}-\mathrm{HCl}$ for $16 \mathrm{~h}$ at $100-110^{\circ} . \mathrm{HCl}$ was then removed by evaporation and the amino acids were resuspended in $3.5 \mathrm{ml} 0.5 \mathrm{M}$-sodium citrate, $\mathrm{pH} \mathrm{6.3.}$

Phenylalanine was converted into $\beta$-phenylethylamine (Garlick et al. 1980), which was assayed by fluorospectrometry (495 nm emission, $390 \mathrm{~nm}$ excitation) with ninhydrin and Lleucylalanine (Suzuki \& Yagi, 1976).

\section{Calculations}

The FSR (\% per d) were calculated using the method described by Garlick et al. (1980). For better estimating of tissue protein FGR, twenty additional chicks were killed per diet group. The livers and the left pectoralis major muscles were rapidly excised and the same procedures were performed as those used for the tissue samples that had been removed for measuring protein synthesis. We therefore determined tissue-protein mass for thirty-seven or thirty-eight chicks per dietary treatment. Regressions were established for each treatment between total tissue protein mass and empty body weight $\left(r^{2} 0.97-0.98\right.$ for the pectoralis major muscle; $r^{2} 0.91-0.92$ for the liver). We thus deduced the amount of tissue protein gained per $\mathrm{g}$ body-weight gained. The tissue protein gained per day $(\mathrm{mg}$ protein $/ \mathrm{d}$ ) was calculated for each chick used for protein synthesis measurements from its daily growth rate $(\mathrm{g} / \mathrm{d})$. FGR was finally derived from the daily change in tissue protein amount divided by the total tissue protein mass present on the day of the experiment. This method, taken from McDonald \& Swick (1981), provides a crude estimate of the fractional growth rates. The rates of protein breakdown (FBR) were estimated as the difference between synthesis rates and growth rates in muscle, or ( $0.7 \mathrm{FSR})$ and FGR in liver to take account of exported proteins (Goldspink \& Kelly, 1984).

Absolute rates of protein turnover, i.e. the total amounts of protein synthesized, gained or degraded each day (ASR, AGR or ABR respectively, g protein/d) in liver or in pectoralis major muscle were calculated by multiplying FSR, FGR or FBR by total tissue protein content present on the day of the experiment. The capacity for protein synthesis, i.e. ribosomal capacity (Cs), was estimated as the RNA:protein ratio ( $\mu \mathrm{g} \mathrm{RNA} / \mathrm{mg}$ protein) because most of the RNA in tissues is ribosomal. We determined the translational efficiency (kRNA) by calculating the amount of protein synthesized per mg RNA and per day (mg protein/(mg RNA per d)).

\section{Statistical methods}

Values are given as means with their standard errors. Two-way ANOVA was performed to discriminate between the effects of age and diets and their interaction in the whole population ( $n 35$ ). Variance analysis and variance-covariance analysis were also performed at each age to study the effect of dietary lysine deficiency in 2-, 3- and 4-week-old chickens.

\section{RESULTS \\ Effects of age}

Growth performances, tissue wet weight, protein and RNA contents increased significantly $(P<0.001$; Table 2$)$ during the experimental period. Over the 2-week period the gain of tissue wet weight and protein mass corresponded to simultaneous increases in the amounts of proteins synthesized and degraded each day (ASR and ABR, Tables 3 and 4). ASR and ABR increased by approximately $2 \cdot 4$-fold in liver on both diets, about $2 \cdot 6$-fold in the pectoralis major muscle on diet $\mathrm{L}$ and by different amounts (2.4- and 4.2-fold respectively) for ASR and ABR on diet $C$. Since the muscle protein content was increased more than ASR, by 3.9- to 4.3-fold, the proportion of protein synthesized daily (FSR; Table 3) was decreased. In contrast in liver, as ASR and protein content increased by similar amounts, FSR was unchanged. 
TISSUE PROTEIN TURNOVER IN CHICKS

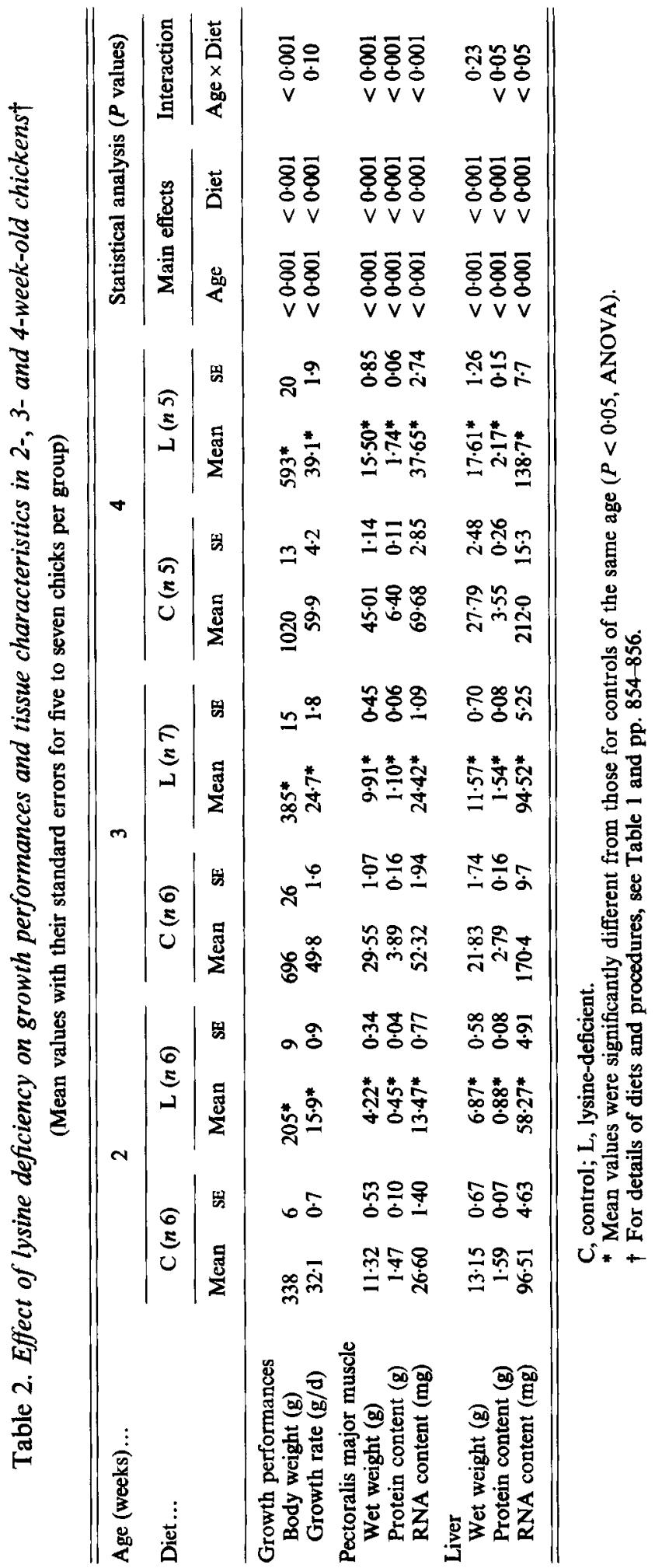




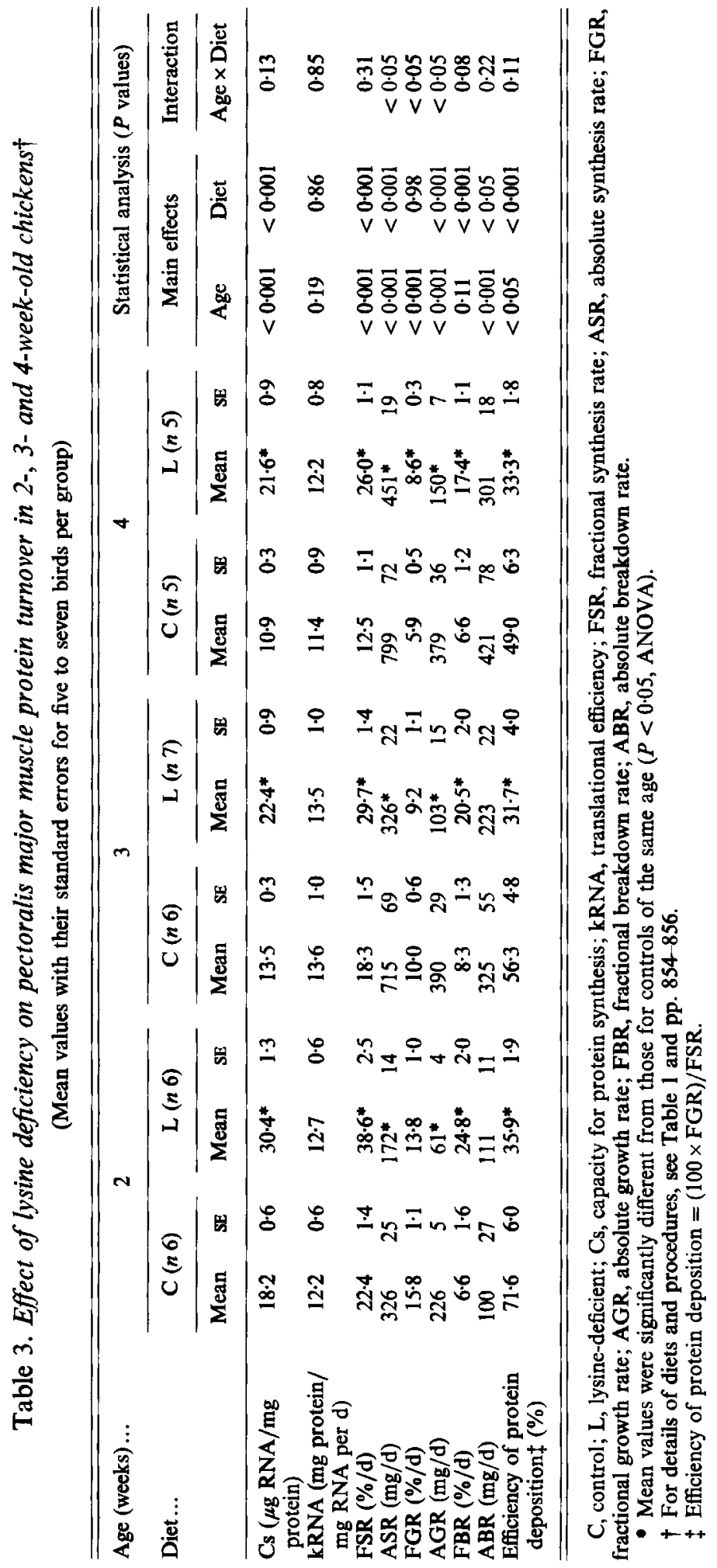




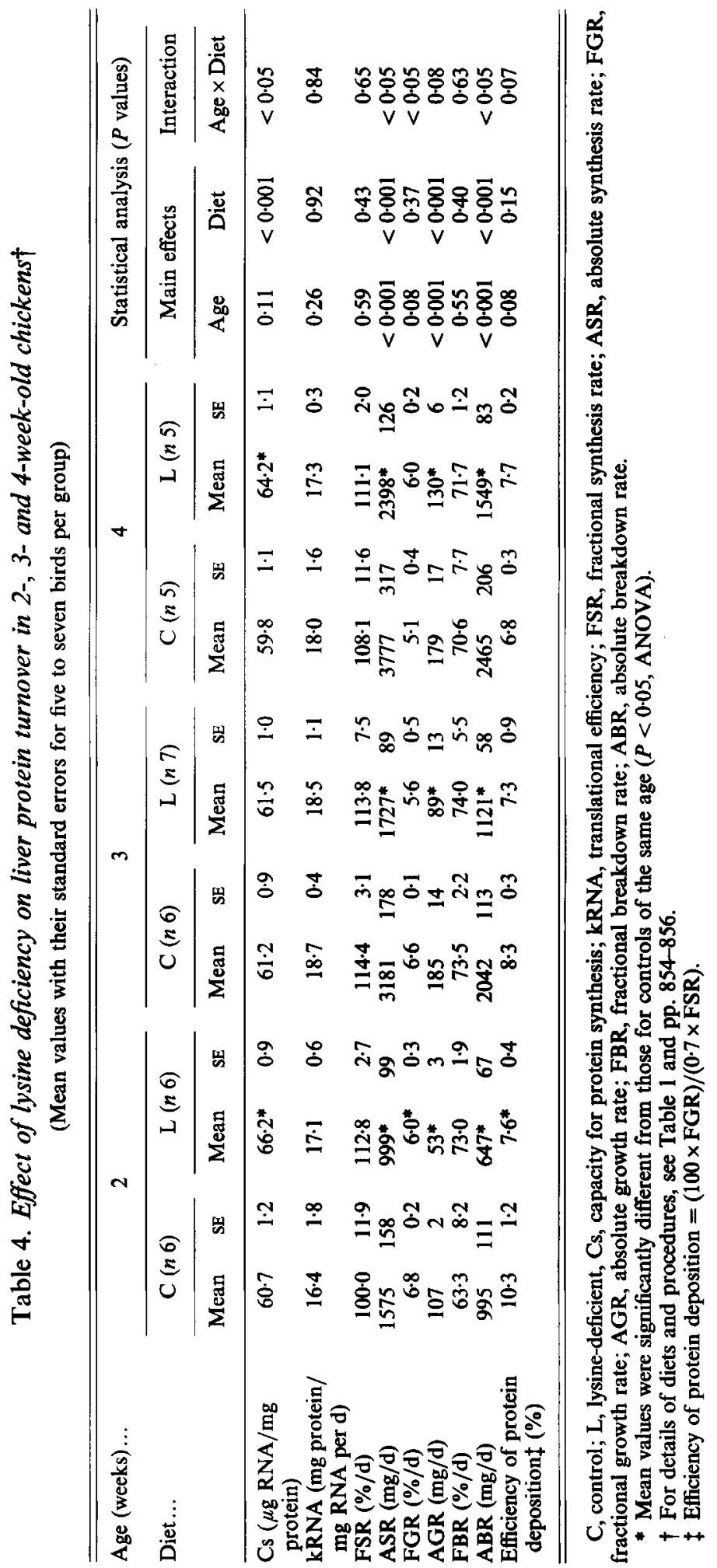




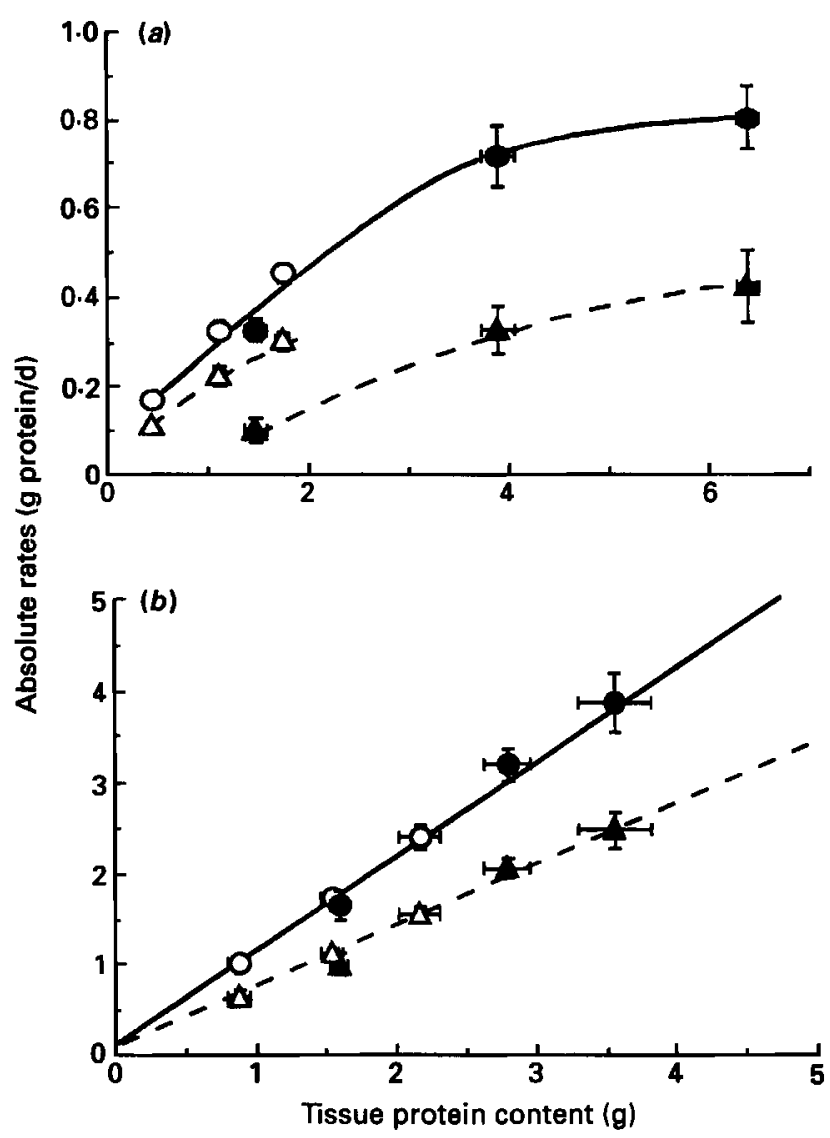

Fig. 1. Protein synthesis $(O, O)$ and breakdown $(\Lambda, \Delta)$ as a function of tissue protein weight in (a) the pectoralis major muscle and (b) the liver of chicks fed on a lysine-deficient diet $(0, \Delta)$ or a control diet $(O, \Delta)$. Values are given as means for five to seven chicks at 2, 3, and 4 weeks of age. Regressions were established between tissue protein weight (PROT) and either protein synthesis (ASR, g/d) or protein breakdown (ABR, g/d). Equations are given in Table 5 .

\section{Effects of lysine deficiency}

Body weights, tissue wet weights, protein and RNA contents were lower $(P<0.001)$ in animals fed on the $L$ diet than in the control group of the same age. Furthermore, wet weight of pectoralis major muscle relative to body weight $(\mathrm{kg})$ was reduced by $40 \%$ when a lysine-restricted diet was given. By contrast, liver weight relative to body weight $(\mathrm{kg}) \mathrm{did}$ not differ significantly between diets.

Two-way ANOVA performed with all animals showed very significant effects of diet on absolute rates of protein turnover expressed in $\mathrm{g}$ protein/d (Tables 3 and 4). First, whatever the tissue, protein deposition was decreased by lysine deficiency $(P<0.001)$ by 73,74 and $60 \%$ in pectoralis muscle at 2,3 and 4 weeks of age respectively and by 50,52 and $27 \%$ in liver. Thus, protein synthesis was reduced by an average factor of 1.8. Protein breakdown clearly $(P<0.001)$ decreased in liver $(-35$ to $-45 \%$ according to age). In the pectoralis major muscle we also recorded a significant effect of diet $(P<0.05)$ with slighter changes in ABR ( $+11 \%$ at 2 weeks of age and approximately $-30 \%$ at 3 and 4 weeks of age). Like the analysis of age effects, the variations in tissue protein mass caused some differences in protein turnover when results were expressed in absolute or fractional terms. Whatever the 
Table 5. Equations of the regressions established between absolute rates of protein turnover (synthesis $A S R$; breakdown $A B R ; g / d)$ and protein weight $(P R O T, g)$ in the pectoralis major muscle and in the liver of chicks fed on a lysine-deficient diet $(L)$ or a control diet $(C)^{*}$

\begin{tabular}{|c|c|c|c|c|}
\hline Tissue/diet & $n$ & Equation & $R^{2}$ & RSD \\
\hline \multicolumn{5}{|l|}{ Pectoralis } \\
\hline $\mathrm{L}$ and $\mathrm{C}$ & 35 & ASR $=0.069+0.235\left(\right.$ SE 0.035) PROT $-0.019\left(\right.$ SE 0.005) $\mathrm{PROT}^{2}$ & 0.86 & 0.092 \\
\hline L & 18 & $\mathrm{ABR}=0.009+0.249(\mathrm{SE} 0.101)$ PROT $-0.047(\mathrm{SE} 0.045) \mathrm{PROT}^{2}$ & 0.79 & 0.043 \\
\hline $\mathbf{C}$ & 17 & $\mathrm{ABR}=-0.096+0.147(\mathrm{SE} 0.079) \mathrm{PROT}-0.010(\mathrm{SE} 0.010) \mathrm{PROT}^{2}$ & 0.60 & 0.124 \\
\hline \multicolumn{5}{|l|}{ Liver } \\
\hline$L$ and $C$ & 35 & $A S R=0.125($ SE 0.155) $+1.031($ SE 0.070) PROT & 0.87 & 0.376 \\
\hline$L$ and $C$ & 35 & $\mathrm{ABR}=0.075(\mathrm{SE} 0.105)+0.669(\mathrm{SE} 0.047)$ PROT & 0.86 & 0.256 \\
\hline
\end{tabular}

RSD, residual standard deviation.

* Corresponding curves are shown in Fig. 1.

age, the reduction of muscle protein mass by about 3.5-fold (Table 2 ) led to significant increases in FSR and ribosomal capacity Cs (160-210\% of the value in the $C$ birds) and particularly in FBR (250-375\%; Table 3). Therefore lysine deficiency resulted in lower efficiencies of muscle protein deposition despite increased rates of protein turnover. In contrast to muscle, liver FSR and FBR were not influenced by the diets since the decreases in both absolute rates and protein mass were in the same range, approximately $1.5-$ to 1.8-fold (Table 4).

We analysed the effect of lysine deficiency by comparing chicks at the same chronological age, when chicks fed on $\mathrm{L}$ or $\mathrm{C}$ diets had different body weights, tissue weights and protein contents. To take this problem into account we plotted absolute rates of protein turnover against tissue protein weight (Fig. 1). For the pectoralis major muscle, polynomial regressions were established (Table 5). As for protein synthesis (ASR), no difference between diets was observed. In contrast, chicks fed on the $\mathbf{L}$ diet seemed to degrade higher amounts of muscle proteins than the control group. This is confirmed by the ABR: protein weight ratios, which reached $0.248,0.203$ and 0.173 with the $L$ diet, and $0.068,0.084$ and 0.065 with the $\mathrm{C}$ diet in 2-, 3- and 4-week-old chicks respectively. For the liver, linear regressions were established (Table 5) in which chicks fed on $\mathrm{C}$ or $\mathrm{L}$ diets could not be discriminated. Indeed, whatever the component of protein turnover (ASR or ABR), covariance analysis using the liver protein weight as a covariate indicated that this covariate had a significant effect $(P<0.001)$ and that there was no difference between diets $(P>0.80)$.

\section{DISCUSSION}

We compared tissue-protein turnover in young growing chicks aged 2, 3 or 4 weeks and fed on either a control diet (C) (adequate diet according to the requirements of growing chicks) or a lysine-restricted diet $(\mathrm{L})$ which contained $76 \%$ of the lysine in the $\mathrm{C}$ diet. The results reported here show that tissue protein turnover was greatly affected by age and lysine deficiency and its responses varied in liver and skeletal muscle. The higher reduction of protein mass in muscle compared with liver resulted from increases in muscle fractional rates (FSR and especially FBR), whereas liver FSR and FBR were unchanged. Finally, we observed that when birds of the same weight were compared the conclusions were different from those drawn from an age comparison. Thus, the reduced rates of muscle protein accretion as a result of amino acid imbalance appear to be due mainly to changes in the rate of protein degradation. 


\section{Effect of lysine deficiency}

Our results demonstrated that whatever the tissue or the age, lysine deficiency reduced the amount of protein gained each day (AGR, g/d). Protein turnover is extremely sensitive to food intake (Arnal et al. 1987; McNurlan \& Garlick, 1989; Muramatsu, 1990) and the protein deposition is influenced by the nature or the quality of proteins (amino acid balance) as well as by the energy intake and the amount of dietary protein. In the present experiment we could not determine whether the diet-induced variations of protein turnover were due to the decrease in protein quality per se or to the consequent alterations in protein or non-protein energy intake since feed intake was reduced approximately $1 \cdot 5$-fold in the $\mathbf{L}$ groups compared with the controls. Whatever the age, neither the feed intake:bodyweight gain ratios nor the feed intake: body weight ratios were lower in chicks fed on the $\mathrm{L}$ diet (results not shown). Thus we may speculate that decreased protein deposition in $\mathrm{L}$ groups did not result primarily from a deficiency in protein and/or energy.

\section{Tissue-specific changes}

In avian species, most studies have been carried out on the regulation of whole-body rather than tissue-protein turnover. However, a change (or lack of change) in whole-body protein turnover does not necessarily mean that all body components respond equally or in the same direction. In the present experiment, therefore, we measured fractional rates of protein synthesis and breakdown in skeletal muscle as well as in liver. The tissue FSR observed here in 2-week-old chicks are similar to the few previous values obtained in chicks of the same age, e.g. $20-25 \%$ per $d$ in the biceps muscle and $95-110 \%$ per $d$ in liver (Nieto et al. 1994).

The pectoralis major muscle seemed more sensitive than the liver to lysine deficiency: whatever the age, we recorded a higher decrease in tissue weight $(-65 v .-40$ to $-50 \%$ in pectoralis major and liver respectively) and in protein deposition (at 2 and 3 weeks of age: $-75 v .-50 \%$ in pectoralis major and liver respectively; at 4 weeks of age: $-60 v .-25 \%$ ). Moreover, we showed that the efficiency of protein deposition declined considerably in the pectoralis major muscle, whereas we observed only a slight change in the liver. The difference of tissue response could be due to the fact that the liver may be protected from diet-induced atrophy on account of its vital properties, unlike the breast muscle which is a product of genetic selection, has little functional utility and could become a major source of amino acids in deficiency states. A higher loss of skeletal muscle mass compared with liver mass and differential changes in protein turnover occurring in each tissue are consistent with results obtained in various catabolic states such as ageing (Mosoni et al. 1995) or sepsis (Vary \& Kimball, 1992a,b). In addition, it could be speculated that liver is less sensitive since it is supplied with nutrients before muscle.

\section{Opposite responses of muscle absolute synthesis rate and fractional synthesis rate}

Because of the large reduction in muscle mass the FSR (\% per d) and ASR (g/d) responded in opposite directions irrespective of age. On the one hand, lysine deficiency resulted in decreases in ASR, in agreement with the results obtained in growing chickens (Tesseraud et al. 1992), in growing pigs (Salter et al. 1990) and in humans (Conway et al. 1980; Meredith et al. 1986). On the other hand, it led to increases in FSR, in keeping with our previous results (Tesseraud et al. 1992). This observation apparently conflicts with the results of Kino \& Okumura (1987), who recorded a reduced FSR in whole body in chicks fed on $\mathrm{S}$ amino acid- or histidine-devoid diets (diets completely lacking in an amino acid). Differences between the results could be attributed to the following reasons. The amino acid in question may be important since Kino \& Okumura (1987) recorded lower FSR with 
a methionine + cystine-free diet than with a histidine-devoid one. Other possibilities are the severity of amino acid deficiency, as suggested by McDonald \& Swick (1981) for protein restriction, and the genotypes used (more or less fast-growing chicks; see review by Griffin \& Goddard, 1994); finally, the results might vary in accordance with the measurement of protein turnover performed in the whole body or in particular tissues and organs. The present investigation provides at least the evidence that lysine deficiency does not change FSR and FBR in liver, in contrast to muscle.

\section{Influence of diet-induced delay in chick development}

The first apparent effect of lysine deficiency was to reduce the body weight so that a 3-weekold chick fed on diet $\mathrm{L}$ was similar in weight and development to a 2-week-old control. Therefore the modifications of protein metabolism could simply be related to a delay in development. Indeed, between 2 and 4 weeks of age we obtained a developmental decline of FSR in the pectoralis major muscle, which is in good agreement with the results found in whole body or skeletal muscle of chickens (McDonald \& Swick, 1981; Muramatsu \& Okumura, 1985; Tesseraud et al. 1994) as well as in whole chick embryos (Muramatsu et al. 1987). Note that age-related decreases in FSR were related to decreased capacities for protein synthesis, whereas the translational efficiency was not significantly modified, as previously reported in mammals (Attaix et al. 1988; Lobley, 1993). Consequently this hypothesis could explain the relatively similar muscle FSR when comparing 2-week-old chicks on diet $\mathrm{C}$ with 3 - or 4 -week-old chicks on diet $\mathrm{L}$. The fact that muscle FBR was always higher in chicks fed on a lysine-deficient diet suggests, however, that the dietary treatment results not only in delayed development but also induces great changes in muscle protein metabolism.

The results presented also suggest that the effect of lysine deficiency on either protein synthesis or degradation depends on whether one compares for equal weights or ages. First, with comparisons at the same age the reduced protein deposition seems to be due mainly to decreases in protein synthesis. This is in keeping with the results obtained with lysinedeficient diets either in growing chicks (Tesseraud et al. 1992) or pigs (Salter et al. 1990). Only Fuller et al. (1987) failed to agree since they found a decrease of protein deposition in growing pigs without any significant changes in protein synthesis or breakdown. Second, a different conclusion is reached when comparing chicks of similar weight or muscle protein content: thus, muscle protein degradation was always higher in the L group, whereas synthesis was unchanged (Fig. 1 and Table 5). Similarly, if one compares 2-week-old birds on diet $\mathrm{C}$ with 3- or 4-week-old birds on diet $\mathrm{L}$, which present similar protein contents at $1.47,1.10$ and $1.74 \mathrm{~g}$ respectively, the striking effect of lysine deficiency is on the FBR. Indeed FBR is more than double, in the lysine-deficient 3- or 4-week-old chicks, that in the controls aged 2 weeks, whereas ribosomal capacity and FSR are similar, and the translational efficiency is identical. Compared in this way, prolonged lysine deficiency may affect muscle mass by changing protein degradation rates, as suggested by other experiments in chicks with mild dietary treatments, e.g. slight protein restriction (Maruyama et al. 1978), amino acid imbalance or feed restriction (Nieto et al. 1994). According to Nieto et al. (1994), only complete fasting reduced muscle FSR. These findings contradict the idea that FBR is less sensitive to dietary treatment than FSR or more generally that degradation rates are primarily regulated by genetic or intrinsic mechanisms, whereas protein synthesis rates are more responsive to nutritional and environmental determinants (see discussion by Tomas et al. 1991). In order to deepen understanding the regulation of tissue protein deposition by dietary factors and particularly dietary protein quality will require further investigations of protein turnover including physiological and hormonal factors. 
We would like to thank G. Kleber for animal care, and N. Maaa, M. Forge and M. Plouzeau for their technical assistance. We are also grateful to J. Grizard, I. Papet, L. Mosoni and P. Patureau-Mirand, INRA Theix, France, for helpful comments.

\section{REFERENCES}

Akinwande, A. I. \& Bragg, D. B. (1985). Effect of the level of dietary lysine on turnover rate of liver protein in the chick. Poultry Science 64, 1938-1940.

Arnal, M., Obled, C., Attaix, D., Patureau, M. P. \& Bonin, D. (1987). Dietary control of protein turnover. Diabete Metabolisme 13, 630-642.

Attaix, D., Aurousseau, E., Bayle, G., Rosolowska-Huszcz, D. \& Arnal, M. (1988). Respective influence of age and weaning on skeletal and visceral muscle protein synthesis in the lamb. Biochemical Journal 256, 791-795.

Conway, J. M., Bier, D. M., Motil, K. J., Burke, J. F. \& Young, V. R. (1980). Whole-body lysine flux in young adult men : effects of reduced total protein and of lysine intake. American Journal of Physiology 239, E192-E200.

Fuller, M. F., Reeds, P. J., Cadenhead, A., Seve, B. \& Preston, T. (1987). Effect of the amount and quality of dietary protein on nitrogen metabolism and protein turnover of pigs. British Journal of Nutrition 58, 287-300.

Garlick, P. J., McNurlan, M. A., Essen, P. \& Wernerman, J. (1994). Measurement of tissue protein synthesis rates in vivo: critical analysis of contrasting methods. American Journal of Physiology 266, E287-E297.

Garlick, P. J., McNurlan, M. A. \& Preedy, V. R. (1980). A rapid and convenient technique for measuring the rate of protein synthesis in tissues by injection of [3H]-Phe. Biochemical Journal 192, 719-723.

Goldspink, D. F. \& Kelly, F. J. (1984). Protein turnover and growth in the whole-body, liver and kidney of the rat from the foetus to the senility. Biochemical Journal 217, 507-516.

Griffin, H. D. \& Goddard, C. (1994). Rapidly growing broiler (meat-type) chickens: their origin and use for comparative studies of the regulation of growth. International Journal of Biochemistry 26, 19-28.

Kino, K. \& Okumura, J. (1986a). The effect of single essential amino acid deprivation on chick growth and nitrogen and energy balances at ad libitum and equalized-food intakes. Poultry Science 65, 1728-1735.

Kino, K. \& Okumura, J. (1986b). Improvement of body weight and nitrogen balance of chicks fed histidine-free or lysine-free diets with supplementation of graded levels of sulfur-containing amino acids. Poultry Science 65, 1736-1740.

Kino, K. \& Okumura, J. (1987). Whole-body protein turnover in chicks fed control, histidine, or methionine plus cystine-free diets. Poultry Science 66, 1392-1397.

Lobley, G. E. (1993). Species comparisons of tissue protein metabolism: effects of age and hormonal action. Journal of Nutrition 123, 337-343.

McDonald, M. L. \& Swick, R. W. (1981). The effect of protein depletion and repletion on muscle-protein turnover in the chick. Biochemical Journal 194, 811-819.

McNurlan, M. A. \& Garlick, P. J. (1989). Influence of nutrient intake on protein turnover. Diabetes/Metabolism Reviews 5, 165-189.

MeNurlan, M. A., Tomkins, A. M. \& Garlick, P. J. (1979). The effect of starvation on the rate of protein synthesis in rat liver and small intestine. Biochemical Journal 178, 373-379.

Maruyama, K., Sunde, M. L. \& Swick, R. W. (1978). Growth and muscle protein turnover in the chick. Biochemical Journal 176, 573-582.

Meredith, C. N., Wen, Z. M., Bier, D. M., Matthews, D. E. \& Young, V. R. (1986). Lysine kinetics at graded lysine intakes in young men. American Journal of Clinical Nutrition 43, 787-794.

Mosoni, L., Valluy, M. C., Serrurier, B., Prugnaud, J., Obled, C., Guezennec, C. Y. \& Patureau Mirand, P. (1995). Altered response of protein synthesis to nutritional state and endurance training in old rats. American Journal of Physiology 268, E328-E335.

Munro, H. N. \& Fleck, A. (1969). Analysis of tissues and body fluids for nitrogenous constituents. In Mammalian Protein Metabolism vol. 3, pp. 424-525 [H. N. Munro, editor]. New York: Academic Press.

Muramatsu, T. (1990). Nutrition and whole-body protein turnover in the chicken in relation to mammalian species. Nutrition Research Reviews 3, 211-228.

Muramatsu, T., Muramatsu, S., Okumura, J. \& Tasaki, I. (1987). Developmental fall in whole body protein turnover of chick embryos during incubation. British Poultry Science 28, 165-172.

Muramatsu, T. \& Okumura, J. (1985). Whole-body protein turnover in chicks at early stages of growth. Journal of Nutrition 115, 483-490.

Nieto, R., Palmer, R. M., Fernandez-Figares, I., Perez, L. \& Prieto, C. (1994). Effect of dietary protein quality, feed restriction and short-term fasting on protein synthesis and turnover in tissues of the growing chicken. British Journal of Nutrition 72, 499-507.

Okumura, J., Mori, S. \& Muramatsu, T. (1985). Relationship between food consumption and energy and nitrogen utilisation by chicks given varying amounts of standard and leucine-, isoleucine- and valine-deficient diets. British Poultry Science 26, 519-525.

Salter, D. N., Montgomery, A. I., Hudson, A., Quelch, D. B. \& Elliot, R. J. (1990). Lysine requirements and whole-body protein turnover in growing pigs. British Journal of Nutrition 63, 503-513. 
Smith, P. K., Krohn, R. I., Hermanson, G. T., Mallia, A. K., Gartner, F. H., Provenzano, M. D., Fujimoto, E. K., Goeke, N. M., Olson, B. J. \& Klenk, D. C. (1985). Measurement of protein using bicinchoninic acid. Analytical Biochemistry 150, 76-85.

Suzuki, O. \& Yagi, K. (1976). A fluorometric assay for phenylethylamine in rat brain. Analytical Biochemistry 75 , $192-200$.

Tesseraud, S., Cammas, J. C. \& Chagneau, A. M. (1994). Effect of age and divergent selection for body weight on muscle protein turnover in chickens. Reproduction Nutrition Development 34, 638-639.

Tesseraud, S., Larbier, M., Chagneau, A. M. \& Geraert, P. A. (1992). Effects of dietary lysine on muscle protein turnover in growing chickens. Reproduction Nutrition Development 32, 163-175.

Tomas, F. M., Pym, R. A. \& Johnson, R. J. (1991). Muscle protein turnover in chickens selected for increased growth rate, food consumption or efficiency of food utilisation: effects of genotype and relationship to plasma IGF-I and growth hormone. British Poultry Science 32, 363-376.

Vary, T. C. \& Kimball, S. R. (1992a). Regulation of hepatic protein synthesis in chronic inflammation and sepsis. American Journal of Physiology 262, C445-C452.

Vary, T. C. \& Kimball, S. R. (1992b). Sepsis-induced changes in protein synthesis: differential effects on fast- and slow-twitch muscles. American Journal of Physiology 262, C1513-C1519. 